Gonf - 950216.-142

\title{
Compositions and Durabilities of Glasses for Immobilization of Plutonium and Uranium IU)
}

by

W. G. Ramsey

Westinghouse Savannah River Company

Savannah River Site

Aiken, South Carolina 29808

N. E. Bibler

T. F. Meaker

A document prepared for WASTE MANAGEMENT '95 CONFERENCE-PAPER FOR PUBLISHED PROCEEDINGS ONLY-ABSTRACT WAS APPROVED 10-13-94. at Tucson from 02/26/95 - 03/02/95.

DOE Contract No. DE-AC09-89SR18035

This paper was prepared in connection with work done under the above contract number with the U. S.

Department of Energy. By acceptance of this paper, the publisher and/or recipient acknowledges the U.S. Government's right to retain a nonexclusive, royalty-free license in and to any copyright covering this paper, along with the right to reproduce and to authorize others to reproduce all or part of the copyrighted paper. 


\section{DISCLAIMER}

This report was prepared as an account of work sponsored by an agency of the United States Government. Neither the United States Government nor any agency thereof, nor any of their employees, makes any warranty, express or implied, or assumes any legal liability or responsibility for the accuracy, completeness, or usefulness of any information, apparatus, product, or process disclosed, or represents that its use would not infringe privately owned rights. Reference herein to any specific commercial product, process, or service by trade name, trademark, manufacturer, or otherwise does not necessarily constitute or imply its endorsement, recommendation, or favoring by the United States Government or any agency thereof. The views and opinions of authors expressed herein do not necessarily state or reflect those of the United States Government or any agency thereof.

This report has been reproduced directly from the best available copy.

Available to DOE and DOE contractors from the Office of Scientific and Technical Information, P.O. Box 62, Oak Ridge, TN 37831; prices available from (615) 576-8401.

Available to the public from the National Technical Information Service, U.S. Department of Commerce, 5285 Port Royal Road, Springfield, VA 22161. 


\section{DISCLAIMER}

Portions of this document may be illegible in electronic image products. Images are produced from the best available original document. 


\title{
COMPOSITIONS AND DURABILITIES OF GLASSES FOR IMMOBILIZATION OF PLUTONIUM AND URANIUM
}

\author{
William G. Ramsey, Ned E. Bibler, and Thomas F. Meaker, Westinghouse Savannah River \\ Company, Savannah River Technology Center
}

\begin{abstract}
Investigations have been performed to determine the suitability of glass as a host for surplus fissile material removed from nuclear weapons. The U.S. Department of Energy - Office of Technology Development has sponsored research at the Savannah River Site to develop durable glass compositions that are compatible with high concentrations of plutonium and uranium. These investigations also being performed to provide baseline actinide glass durability and processing data.
\end{abstract}

Two glass forming systems are being evaluated. One of the systems is a commercial borosilicate glass and the other an iron phosphate glass. Both glass systems have a very high degree of compatibility with actinide oxides and are considerably more durable than conventional high-level waste glasses. The iron phosphate glass has a melting temperature in the $1100^{\circ} \mathrm{C}$ range and has the higher uranium and plutonium solubility. The borosilicate has a melting temperature in the $1425^{\circ} \mathrm{C}$ range and is the more durable (on the order of fused silica) glass.

\section{INTRODUCTION}

As the nuclear weapon arsenals of the United States and the Former Soviet Union are reduced, metric tonnage quantities of fissile material must be dispositioned [1]. One of the potential disposition options for U.S. weapons material is vitrification into a plutonium or uranium glass product [2]. The U.S. Department of Energy - Office of Technology Development has sponsored a program at the Savannah River Technology Center (SRTC) to develop suitable glass formulations for the long term safe storage of uranium and plutonium, as well as americium, neptunium and curium. These "actinide glasses" are the focus of this paper [3].

Three of the most important questions which must be answered for any actinide glass product are (1) what is the maximum actinide oxide loading, (2) what is the chemical durability, and (3) how can it be produced. The experiments described below were performed to provide a preliminary technical baseline on actinide solubility in glass and glass durability. Glass processing characteristics and limits will be discussed in subsequent publications.

This paper discusses the chemical composition and durability of two types of actinide glasses under development. One of the glasses is a commercial borosilicate composition developed in the 1930 's for use as an optical glass [4]. This glass, referred to as the Löffler glass, was selected for study due to the very high (55 weight percent) lanthanide oxide content [5]. Lanthanides are commonly used as actinide surrogates [6]. There was, therefore, a high degree of confidence that this glass would be chemically compatible with high concentrations of actinides. The other glass is an iron phosphate. This glass was selected for study due to the combination of low melting point and high durability $[7,8]$. In the initial studies thorium and uranium were used as the actinides. Because of the low radioactivity of these elements, the glasses could be prepared and tested on the bench top.

The specific objectives of the initial study were to determine: 
maximum weight percent loading of thorium an uranium oxide in the borosilicate and phosphate glass,

(2) chemical durability of the glasses as a function of actinide loading,

Data obtained were used to determine initial frit compositions and processing parameters for the plutonium melts. The first plutonium glasses have been prepared and are being tested in the shielded cell and glovebox facilities at SRTC.

\section{EXPERIMENTAL}

\section{Glass Fabrication}

The initial glass samples fabricated were made from reagent chemicals. The batches were made in high-form alumina crucibles. Water was added to all reagent chemical batches to ensure proper mixing. The batch was allowed to dry overnight at $90^{\circ} \mathrm{C}$ prior to firing. The crucibles were then placed in a furnace and ramped to temperature no faster than $8^{\circ} \mathrm{C}$ per minute. The appropriate melt temperature was held for a period sufficient to ensure complete melting. The glass was then cast into a graphite mold and annealed. Glass frit was produced in the same manner except the melt was cast into water and then crushed into powder.

\section{Glass Durability Testing}

Relative durability of the glasses discussed above was measured using the ASTM C-1285 standard nuclear waste glass durability test method, commonly referred to as the Product Consistency Test, or PCT [9]. The PCT protocol calls for crushed glass powder to be reacted with ASTM-I deionized water in a closed vessel [10]. The test conditions included:

- 10 milliliters ASTM- $\mathrm{H}_{2} \mathrm{O}$ per gram 100-200 mesh glass powder,

- $\quad 90^{\circ} \mathrm{C}$ test temperature,

- 7 day test duration.

PCT leachates were analyzed for soluble glass constituents by Inductively Coupled Plasma Emission Spectroscopy (ICP-ES). U and Th concentrations in the leachates were determined by Inductively Coupled Plasma - Mass Spectroscopy (ICP-MS). Leachate solution $\mathrm{pH}$ was measured by a glass bulb electrode.

Relative glass durability was calculated from the PCT data. Normalized Loss $\left(\mathrm{NL}_{[\mathrm{i}]}\right)$, a common expression of relative glass durability was calculated for each glass tested. $\mathrm{NL}_{[\mathrm{i}]}$ is a function of the concentration of a soluble glass constituent cation in the PCT leachate solution and the concentration of the cation in the glass. $\mathrm{NL}_{[\mathrm{i}]}$ is expressed in the units grams of glass dissolved per liter of leaching solution. The following relationship is used to calculate $\mathrm{NL}_{[\mathrm{i}]}$ :

$$
\mathrm{NL}_{[\mathrm{i}]} \equiv \frac{\mathrm{c}_{[\mathrm{i}]}}{(1000) \mathrm{f}_{[\mathrm{i}]}}
$$

where

$$
\begin{aligned}
& c_{[i]}=\quad \text { concentration of "i" in solution }(\mathrm{mg} / \mathrm{L}), \\
& f_{[i]}=\quad \text { weight fraction of "i" in glass. }
\end{aligned}
$$


X-Ray Diffraction

X-Ray Diffraction was performed on all samples to identify any crystalline phases. Scanning Electron Microscopy was also performed as a complementary technique if crystalline phases were detected. None of the glass samples discussed above had any discernible crystalline character.

\section{RESULTS}

\section{Glass Production}

Minor adjustments to the base Löffler glass composition were made in order to lower the melting point and liquidus temperature and raise the melt viscosity [11,12]. This was accomplished by reducing the total lanthanide oxide content and increasing the alumina, lead oxide, and silica fractions of the glass composition. The compositions of one series of glasses, which bracket the expected process parameters for actinide glass production, are given in Table 1. All glasses shown in Table 1, with the exception of Lan-22, were melted at $1425^{\circ} \mathrm{C}$. Lan-22 was melted at $1460^{\circ} \mathrm{C}$.

Table 1. Composition Range of Non-Radioactive Loffler Glasses Tested (oxide mole percent)

\begin{tabular}{|c|c|c|c|c|c|c|}
\hline Oxide & Lan-14 & Lan-17 & $\underline{\text { Lan-18 }}$ & Lan-19 & Lan-22 & Target \\
\hline $\mathrm{SiO}_{2}$ & 51.7 & 46.4 & 48.1 & 50.5 & 47.6 & 49.4 \\
\hline $\mathrm{B}_{2} \mathrm{O}_{3}$ & 7.8 & 6.9 & 7.4 & 6.8 & 6.3 & 5.4 \\
\hline $\mathrm{BaO}$ & 2.6 & 2.7 & 2.1 & 1.7 & 2.5 & 2.8 \\
\hline $\mathrm{Al}_{2} \mathrm{O}_{3}$ & 16.9 & 19.9 & 18.5 & 17.3 & 18.4 & 18.0 \\
\hline $\mathrm{La}_{2} \mathrm{O}_{3}$ & 9.9 & 5.7 & 9.9 & 10.3 & 9.0 & 5.8 \\
\hline $\mathrm{Nd}_{2} \mathrm{O}_{3}$ & 0.0 & 7.6 & 3.6 & 3.5 & 6.6 & 6.7 \\
\hline $\mathrm{CeO}_{2}$ & 5.5 & 6.0 & 5.6 & 5.3 & 5.2 & 6.9 \\
\hline $\mathrm{PbO}$ & 5.8 & 4.9 & 4.7 & 4.6 & 4.4 & 5.1 \\
\hline
\end{tabular}

The next series of glasses consisted of uranium and thorium oxide added to the target glass composition shown in Table 1. Uranium and thorium oxide were substituted on a 1:1 molar basis for cerium and neodymium oxide. Melts containing 1,5 , and 9 mole percent $(9$ mole percent $\cong 20$ weight percent) uranium oxide (calculation basis $\left.\mathrm{UO}_{2}\right)$ and thoria $\left(\mathrm{ThO}_{2}\right)$ were successfully processed at $1425^{\circ} \mathrm{C}$.

The base composition iron phosphate glass, as shown in Table 2 has a melting point $\cong 1100^{\circ} \mathrm{C}$. No composition adjustment was necessary to the base glass prior to adding uranium or thorium oxide. Thorium and uranium oxide were substituted on a 1:1 molar basis for $\mathrm{Fe}_{2} \mathrm{O}_{3}$. Melts containing 10,14 , and 17 mole percent ( 17 mole percent $\cong 30$ weight percent) actinide oxide were successfully processed at $1150^{\circ} \mathrm{C}$.

Iron phosphate glass frits were made for plutonium processing. Frit and $\mathrm{PuO}_{2}$ were mixed together and then heated to $1100^{\circ} \mathrm{C}$ (5 hours at temperature). Melts containing 10 and 17 mole percent $\mathrm{PuO}_{2}$ were successfully processed. A frit composition (denoted Frit $+\mathrm{Ba}$ ) developed for the plutonium glass melts is shown in Table 2 . 
Table 2. Composition of the Iron Phosphate Base Glass and Frit Glass (oxide mole percent)

$\begin{array}{lrr}\text { Oxide } & \text { Base } & \text { Frit }+\mathrm{Ba} \\ \mathrm{P}_{2} \mathrm{O}_{5} & 55.0 & 66.3 \\ \mathrm{BaO} & 0.0 & 3.6 \\ \mathrm{Na}_{2} \mathrm{O} & 10.0 & 12.0 \\ \mathrm{Fe}_{2} \mathrm{O}_{3} & 35.0 & 18.1\end{array}$

Relative Glass Durability

The Löffler glasses are quite resistant to aqueous attack. The PCT experiments on the nonradioactive glasses (Table 1) show very uniform results. All six Löffler glasses tested were more durable than two common durable glasses - Vycor and fused silica. This is graphically represented in Figure 1. Table 3 lists the PCT leachate Si concentration for the Löffler glasses, fused silica and Vycor. Normalized Release, NR $[\mathrm{Si}]$, and the Glass ID's used in Figure 1 also shown in Table 3.

Thorium and uranium bearing Löffler glasses are also quite resistant to aqueous attack. The PCT results show little or no difference between the durability of actinide bearing and non-radioactive compositions. Also, uranium and thorium oxide appear to have identical effects on glass durability. There is no difference between the durability of glasses with 1 percent and 5 percent actinide oxide content. Glasses with 9 mole percent actinide oxide were slightly less durable. These results are displayed in Figure 2. It should be noted the relative durability of the Löffler glasses is approximately 3 orders of magnitude better than the standard for high-level waste glass $[13,14]$.

The iron phosphate glasses are also quite resistant to aqueous attack. PCT experimental results indicate the iron phosphate glass to be approximately 2 orders of magnitude more durable than the standard for high-level waste glass. Thorium and uranium bearing glasses have similar PCT response up to the 20 weight percent actinide oxide concentration. Both thorium and uranium have a negative effect on the durability of the iron phosphate glass beyond 20 weight percent oxide loading. Beyond twenty weight percent, uranium glasses are appreciably less durable than thorium glasses. These data are graphically represented in Figure 3 . The leachate solutions are also significantly more acidic as the uranium oxide content increases beyond 20 weight percent. These data are graphically represented in Figure 4.

Table 3. Durability Data From Löffler Glasses, Fused Silica, and Vycor

$\begin{array}{lcccccccc} & \text { Vycor } & \text { Silica } & \text { Target } & \text { Lan-14 } & \underline{\text { Lan-17 }} & \underline{\text { Lan-18 }} & \underline{\text { Lan-19 }} & \underline{\text { Lan-22 }} \\ \text { ppm Si } & 54.3 & 26.4 & 1.12 & 2.00 & 3.25 & 1.12 & 2.24 & 1.34 \\ \text { NL[Si] } & 0.121 & 0.057 & 0.010 & 0.015 & 0.030 & 0.010 & 0.019 & 0.011 \\ \text { Glass ID* } & 1 & 2 & 3 & 4 & 5 & 6 & 7 & 8\end{array}$

* Denotes the ID used on the $\mathrm{x}$-axis of Figure 1. 


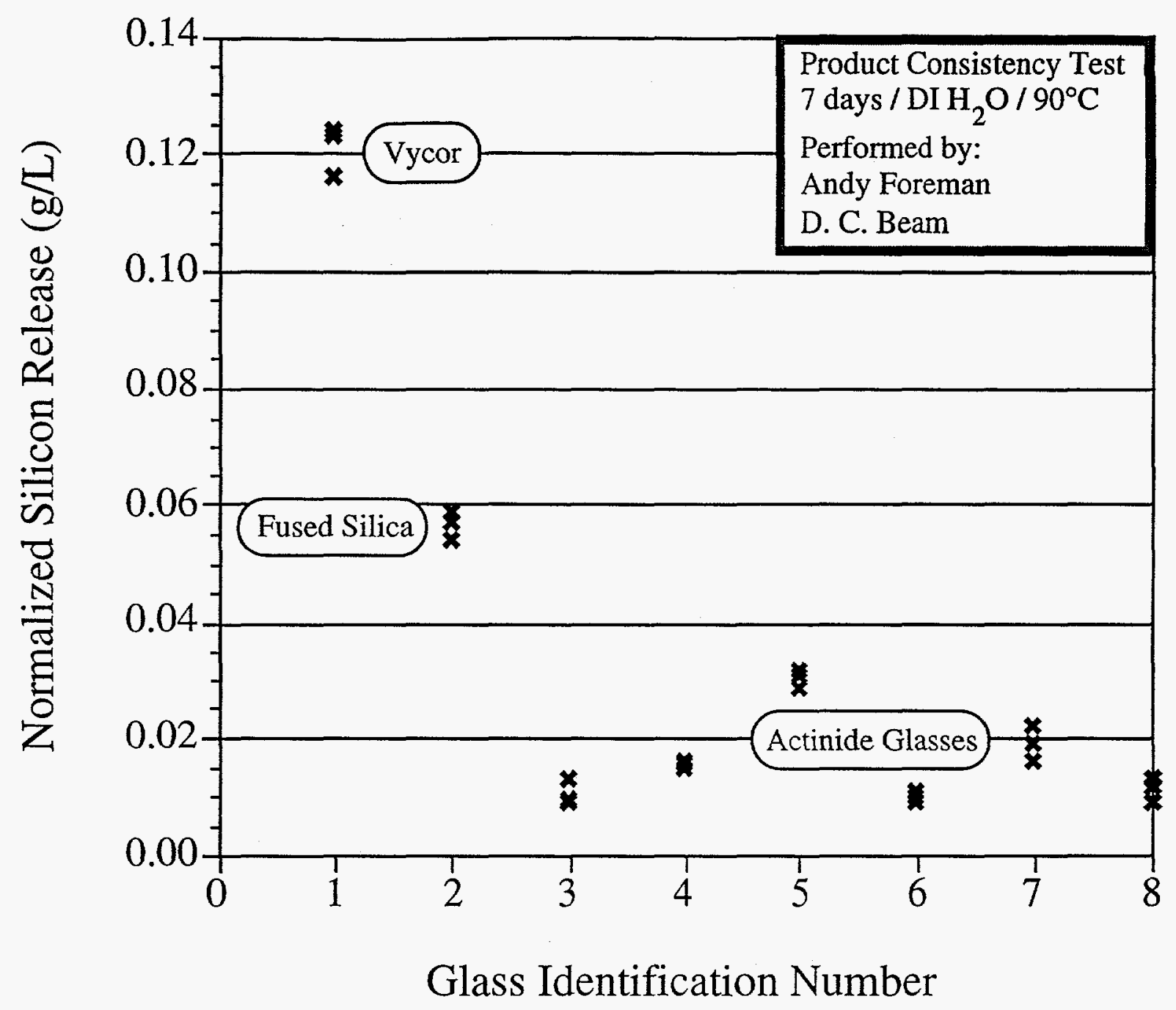

Figure 1. Relative Durability of Löffler Glass as determined by the Product Consistency Test 


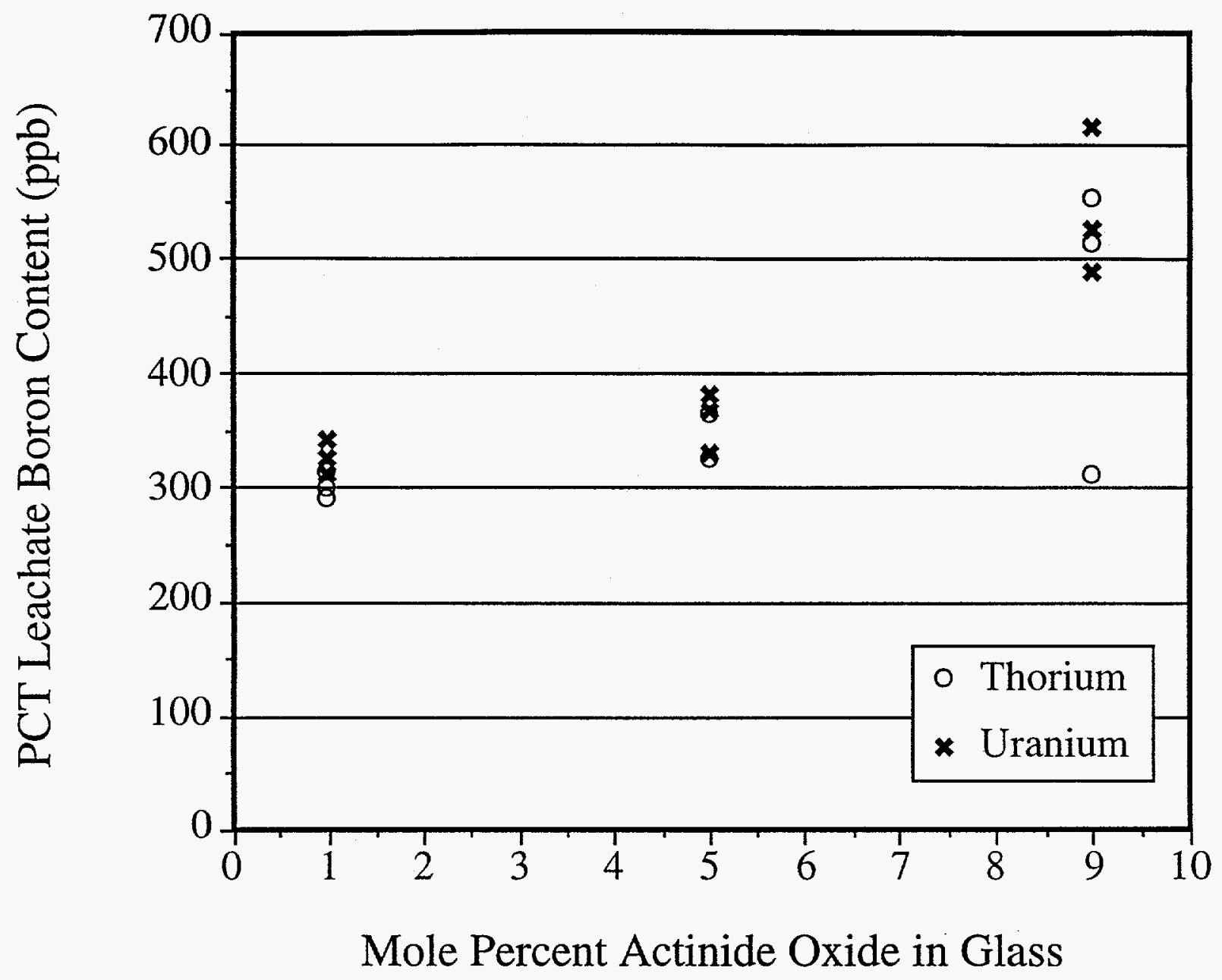

Figure 2. Effect of Actinide Oxide Content on Löffler Glass Durability 


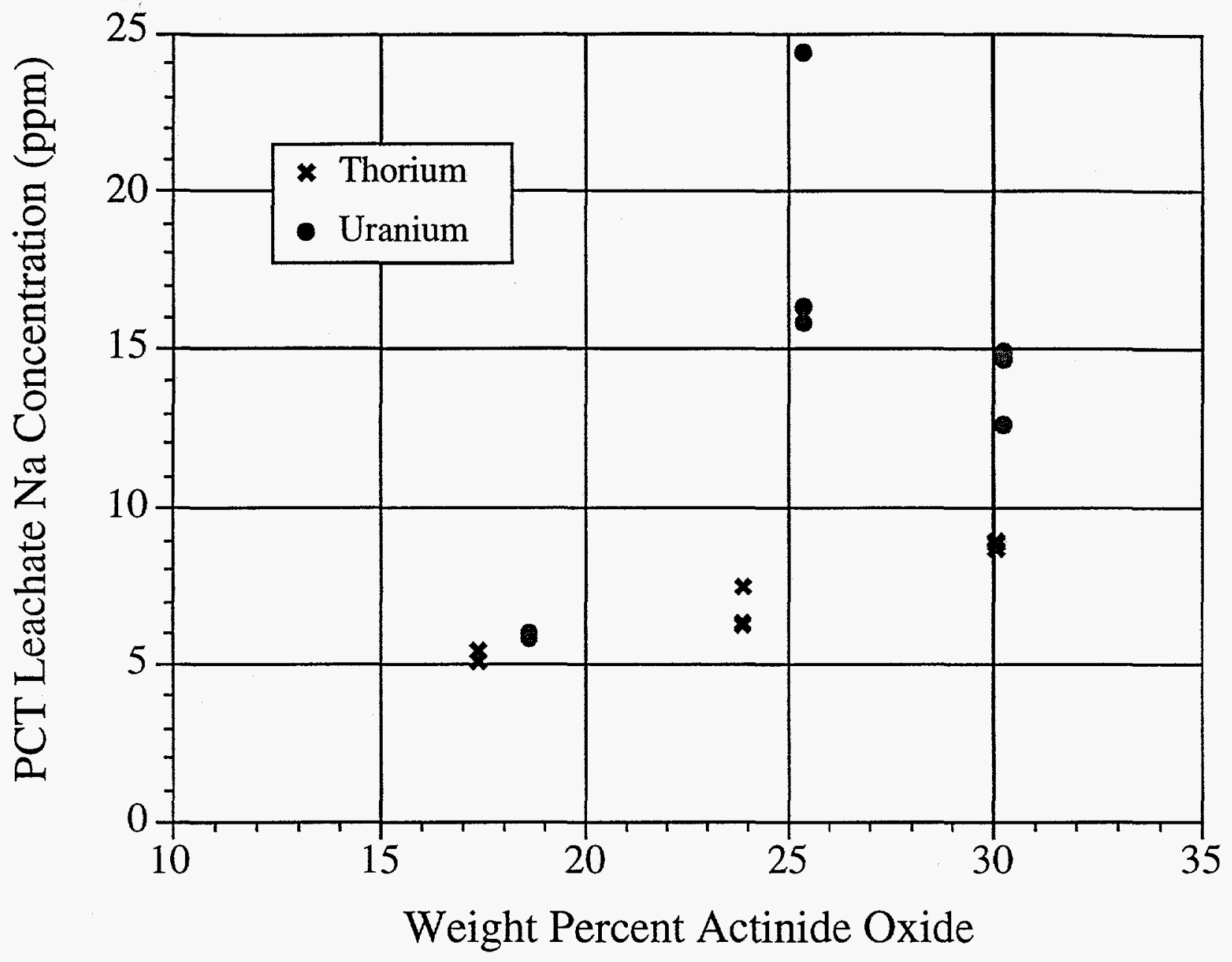

Figure 3. Effect of Actinide Oxide Loading on Iron Phosphate Glass Durability 


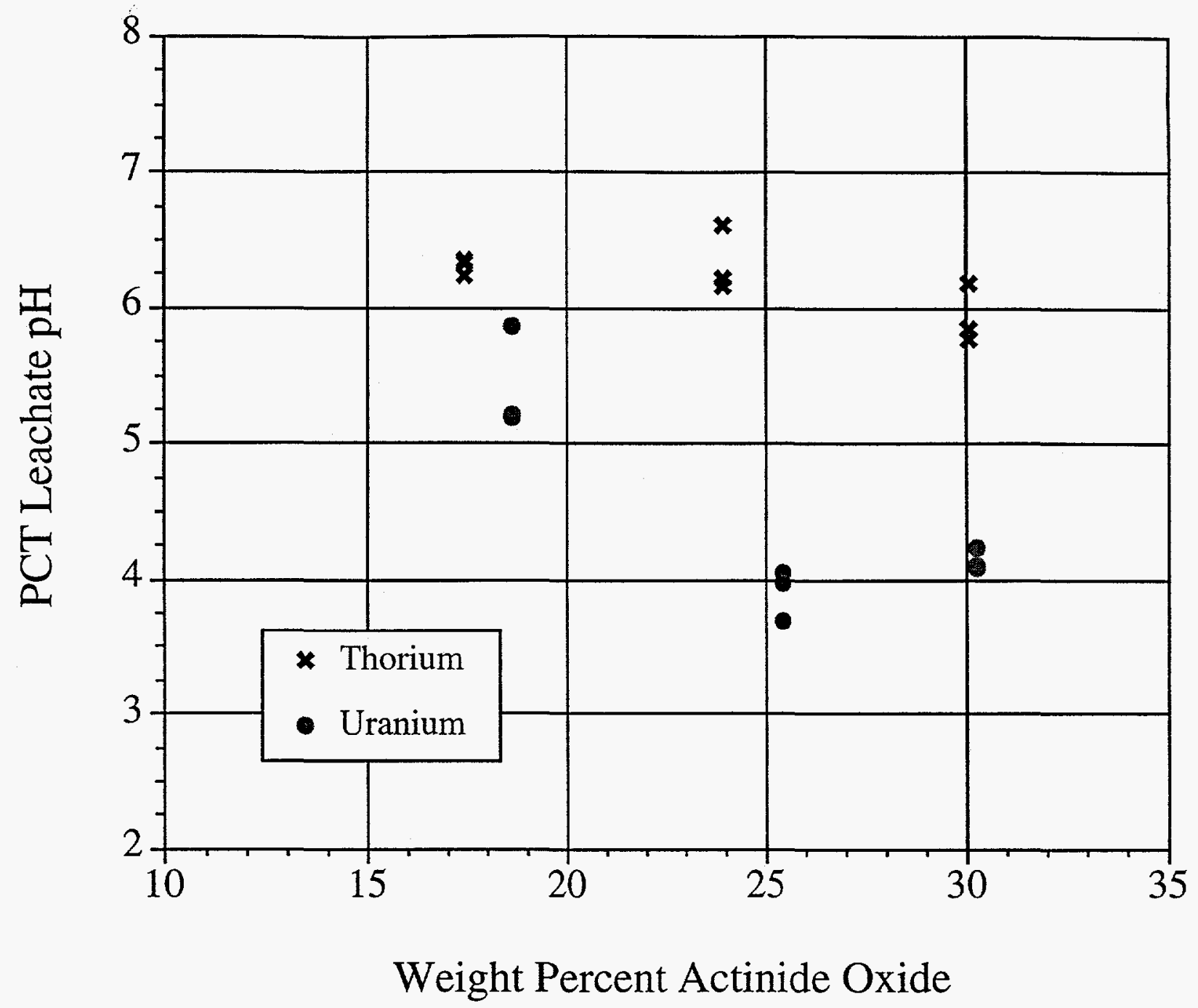

Figure 4. Acidity of Iron Phosphate Glass Leachate Solutions

\section{DISCUSSION}

The Löffler and iron-phosphate glass compositions with high concentrations of actinides. Also, both glasses are extremely resistant to aqueous corrosion. Interestingly, the Löffler and iron phosphate glass are completely different chemically. The base compositions share no common oxides. Löffler glasses are processed at temperatures consistent with commercial borosilicate glasses. Iron phosphates are processed at temperatures $300^{\circ} \mathrm{C}$ lower, in the range of high-level waste glasses. It is felt, therefore, that these glasses may be used for different actinide vitrification missions - in the manner of complimentary products. The Löffler glass has been selected as the optimum glass formulation for vitrification of SRS americium and curium [11]. This glass is compatible with existing commercial melters and appears well suited for mass production. It is completely compatible with lanthanide neutron poisons ( $\mathrm{Gd}, \mathrm{Sm}, \mathrm{Eu})$ and, certainly, boron. The use of dual neutron poisons in the frit and glass compositions has obvious safety benefits. 
The iron phosphate does not have the same degree of compatibility with lanthanide neutron poisons as the Löffler glass, but is easily processed in low temperature furnaces. Moreover, the glass appears to be fairly tolerant of fluoride and reducing agents. For this reason, the iron phosphate is being proposed for disposition of heterogeneous, sub-critical masses of plutonium by direct vitrification. This should significantly lessen the number of pretreatment processes which must be developed to handle existing U.S. plutonium inventories.

\section{CONCLUSIONS}

There are four principal conclusions.

1) The solubility of thorium and uranium oxide in a representative Löffler borosilicate glass is approximately 9 mole percent ( 20 weight percent).

2) The durability of the Löffler borosilicate glass is extremely high, equivalent or better than fused silica. Thorium and uranium oxides have identical effects on Löffler glass durability.

3) The solubility of plutonium, uranium, and thorium oxide in the iron phosphate glass is approximately 17 mole percent ( 30 weight percent).

4) The durability of the iron-phosphate glass is considerably better than the standard for high-level waste glass. Glasses with high concentrations of uranium are slightly less durable than corresponding thorium bearing glasses.

The Löffler composition is the recommended glass composition for vitrification of SRS Am and $\mathrm{Cm}$. The original composition has been tailored to be more compatible with the tetravalent actinide oxides and existing commercial melter systems. Based on the processability and extremely high chemical durability, it is concluded that this glass should also be considered for vitrification of metric tonnage quantities of weapons plutonium and uranium.

The iron phosphate glass has extremely high chemical compatibility with actinide oxides. It also has a high chemical durability and can be easily processed on the crucible scale. Based on these data, this glass should be considered suitable for disposition of small, heterogeneous sources of plutonium and uranium.

\section{ACKNOWLEDGMENT}

This work was performed in connection with work done under Contract No. AC09-89SR18035 with the U.S. Department of Energy and under Task Technical Plan SR 14-20-08 sponsored by the U.S. Department of Energy - Office of Technology Development. 


\section{REFERENCES}

1) "Management and Disposition of Excess Weapons Plutonium," Committee on International Security and Arms Control, National Academy of Sciences, National Academy Press, Washington DC, 1994.

2) J. M. MCKIBBON, et al., Vitrification of Excess Plutonium (U), WSRC-RP-93-755, Predecisional Draft, Westinghouse Savannah River Company, Aiken SC, 1993.

3) "Vitrification Process demonstration: Safe, Permanent Storage of Transuranic Elements," Technical Task Plan SR1-4-20-08, U.S. Department of Energy - Office of Technology Development.

4) MILOS VOLF, "Chemical Approach to Glass," pp 391-405, Elseveier Press, 1984.

5) J. VON LOFFLER, "Chemical Decolorization," Glastechniche Berichte, 10, pp 204-211, 1932.

6) J. J. KATZ, G. T. SEABORG, and L. R. MORSS, "The Chemistry of the Actinide Elements, 2nd Edition," Volume 1, Chapman and Hall, 1986.

7) J. A. WILDER, D. E. DAY, and B. C. BUNKER, "Preparation and Properties of Phosphorous Oxynitride Glasses," Glastechniche Berichte, 56K, Vol. 2, pp 845-849, 1982.

8) B. P. MCGRAIL, D. E. DAY, and A. KUMAR, "Sodium Diffusion and Leaching of Simulated Nuclear Waste Glass," Journal of the American Ceramic Society, 67 (7), pp 463-467, 1984.

9) Standard C1285, "Test Method for Determining Chemical Durability of Nuclear Waste Glasses: the Product Consistency Test (PCT)," American Society for Testing and Materials 94-1, Item 13, 1994.

10) C. M. JANTZEN, N. E. BIBLER, D. C. BEAM, and W. G. RAMSEY, "Nuclear Waste Product Consistency Test (PCT) - Version 5.0," WSRC-TR-90-539, Rev. 2, Westinghouse Savannah River Company, Aiken SC,1992.

11) W. G. RAMSEY, et al., "Vitrification of F-Area Americium/Curium: Feasibility Study and Preliminary Process Recommendation," WSRC-TR-94-0211, Westinghouse Savannah River Company, Aiken SC, 1994.

12) W. G. RAMSEY, B. J. HARDY, and T. F. MEAKER, "Vitrification of H-Area Neptunium: Feasibility Study and Preliminary Process Recommendation," WSRC-TR-940211, Westinghouse Savannah River Company, Aiken SC, 1994.

13) C. M. JANTZEN, N. E. BIBLER, and D. C. BEAM, "Characterization of the Defense Waste Processing Facility (DWPF) Environmental Assessment (EA) Glass Standard Reference Material (U)," WSRC-TR-92-346, Westinghouse Savannah River Company, Aiken SC, 1992.

14) USDOE Report WSRC SW 4-6, Rev. 0, Wasteform Compliance Plan for the Defense Waste Processing Facility, Westinghouse Savannah River Co., Savannah River Site, Aiken, SC, 1988. 